Gut, 1983, 24, 1048-1056

\title{
Epithelial cell proliferation in the rectal stump of patients with ileorectal anastomosis for ulcerative colitis
}

\author{
T LEHY, M MIGNON, AND J L ABITBOL
}

From the Unité de Recherches de Gastroentérologie, INSERM U10, and Clinique des Maladies de l'Appareil Digestif, Hôpital Bichat, Paris, France

SUMMARY Epithelial cell proliferation in the rectal stump after ileorectal anastomosis for ulcerative colitis was studied in 19 patients. This was achieved through in vitro incorporation of tritiated thymidine in mucosal biopsies and radioautographic analysis of the number and position of labelled nuclei in the crypts. Rectal biopsies from nine unoperated patients with ulcerative colitis and from 10 controls, were processed simultaneously. Except for one, all patients were clinically in remission. The crypt length and number of labelled cells per crypt column were found to be similar in the rectal mucosa from the three groups of subjects. The mean labelling index, although low $8.9 \%$, was higher $(\mathrm{p}<0.05)$ in operated patients compared with controls; but the dispersion of individual values was similar in both groups. There was an extension of the proliferative compartment towards the surface in $88 \%$ of unoperated patients and in $60 \%$ of operated patients. In addition, there was a shift of the major zone of proliferation from the lower to the middle third of the crypt in $17 \%$ of operated patients and from the lower to the upper third of the crypt in $14 \%$ of unoperated patients. No correlation was found between the labelling index and either the age of patient, the duration of disease or the period elapsed after ileorectal anastomosis. Interestingly, among operated patients with a colitis for over 10 years, $42 \%$ had a quite normal proliferative pattern with a corresponding mean postoperative period of 7.5 years.

More than 20 years have elapsed since colectomy and ileorectal anastomosis were introduced as an alternative to proctocolectomy and ileostomy for the surgical management of ulcerative colitis. ${ }^{1}$ Although this surgical attitude has gained increasing support ${ }^{2-3}$ because of the better quality of life it offers to most patients, the risk of developing carcinoma on the rectal stump remains a major problem..$^{2-4}$ The prevalence of rectal malignancy in ileorectal anastomosis seems lower than that noted in extensive longstanding cases of ulcerative colitis. ${ }^{2-7}$ A number of approaches have been used to reliably identify malignant and premalignant epithelium in ulcerative colitis such as analysis of morphology ${ }^{8}$ and cell replication kinetics. ${ }^{9-15}$ Studies conducted in the latter field of investigation have led to the statement of noticeable changes in epithelial cell proliferation in active colitis including either lengthening of turn over time $\mathrm{e}^{9-10}$ or, on the contrary, shortening of the turn over time, ${ }^{11}$

Address for correspondence: Dr T Lehy, INSERM U10, Hôpital Bichat, 170 Bd Ney, F-75877 Paris Cedex 18, PARIS, France.

Received for publication 14 January 1983 accompanied by increase in epithelial cell proliferation, ${ }^{11-13}$ acceleration of cell migration, ${ }^{12}$ extension of the proliferative zone towards the upper part of the crypt. ${ }^{11-13}$ Very recently an extension of DNAsynthesising cells high in the crypt was reported in ulcerative colitis in remission, ${ }^{14-15}$ but the proportion of these cells was found to be increased in only one study. ${ }^{14}$ A lack of inhibition by phosphodiesterase inhibitors of thymidine incorporation into DNA was demonstrated in patients with longstanding colitis although in remission. ${ }^{16}$

In our experience of ulcerative colitis patients with ileorectal anastomosis (unpublished data of survey 1982) one case of Dukes A rectal carcinoma has been recently observed. Up until now, to our knowledge, there has been no published report concerning cell proliferation kinetics in the rectal stump after ileorectal anastomosis for ulcerative colitis. Therefore the present work was undertaken to study some parameters of the rectal epithelial cell proliferation in those of our patients who agreed to participate in this investigation. 


\section{Methods}

PATIENTS

Three groups of patients were studied: Group I. Nineteen patients, 10 men, nine women, median age 43 years (range 16-77 years) who have undergone ileorectal anastomosis for ulcerative colitis. The median duration of disease evolution was 11.6 years (range 1.2-42.7 years), the median period after surgery was four years (range $0 \cdot 6-12.5$ years) (Figs. 1-2).

Group II. Nine patients, four men, five women, median age 45 years (range 19.5-75 years) with chronic ulcerative colitis; the median duration of disease evolution was 15 years (range $2-40$ years) (Figs. 1-2).

In patients of groups I and II the initial diagnosis of ulcerative colitis was based upon the following characteristic features: on the one hand, mucosal inflammation with pseudo-polyps and/or crypt abcesses, continuity of the disease within the colon and on the other hand, the absence of severe fistulas, broad fissures or epitheloid granulomas and of small bowel disease. The extent of colonic involvement was judged either from air contrast barium enema or colonoscopy in unoperated patients or from anatomical features of the surgical specimen in the operated group. Universal colitis is defined as disease extending proximally from the rectum to include the hepatic flexure or the totality

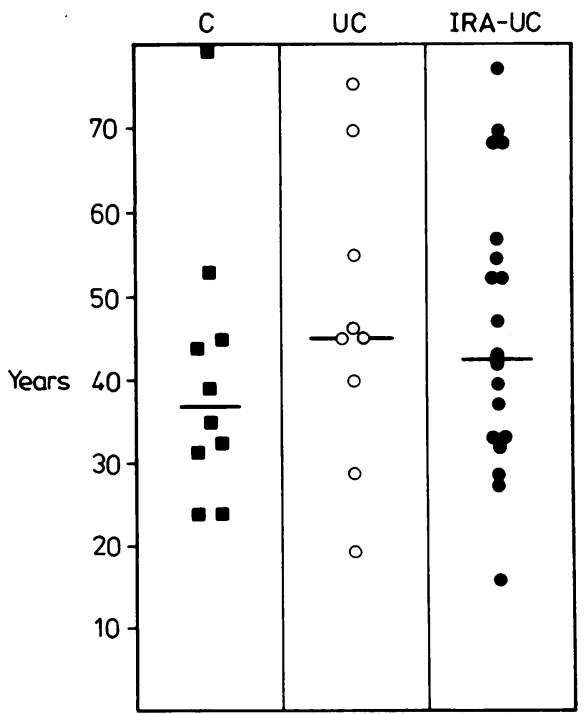

Fig. 1 Individual and median ages in each group of subjects. $C=$ controls, $U C=$ ulcerative colitis, IRA-UC = ulcerative colitis with ileorectal anastomosis.

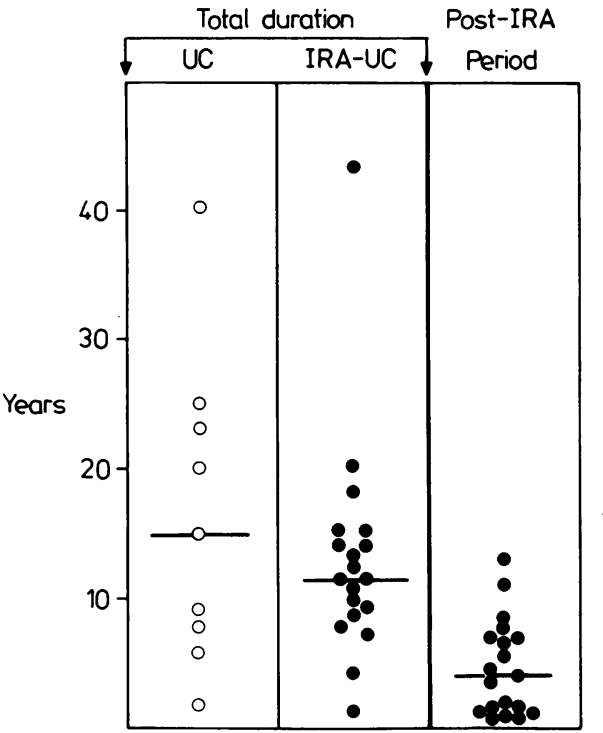

Fig. 2 Individual and median durations of the disease in two groups of patients having ulcerative colitis. Individual and median periods elaspsed after ileorectal anastomosis in the IRA-UC patients group.

of the ascending colon. Left-side colitis is defined as disease commencing distal to midtransverse colon. In group I, 16 patients had universal colitis and three had left-sided colitis at the time of surgery. In group II, five patients had universal colitis, two had left-sided colitis and two had colitis limited to rectum and sigmoid colon.

One ulcerative colitis and four ileorectal anastomosis-ulcerative colitis patients were taking steroids; two ulcerative colitis and one ileorectal anastomosis-ulcerative colitis patients were taking salicylazosulfapyridine at the time of the study. Five patients (one ulcerative colitis and four ileorectal anastomosis-ulcerative colitis) were rebiopsied after an interval of 10-30 months.

Group III. Ten subjects, without any disease of the digestive tract and known family history of cancer, served as controls: seven men and three women, showing endoscopically and histologically normal rectal mucosa, median age 37 years (range 24-79 years) (Fig. 1). Approval for the study was obtained from a Human Research Committee at the Delegation Générale à la Recherche Scientifique et Technique (DGRST).

IN VITRO DNA LABELLING AND

AUTORADIOGRAPHIC PROCEDURES

Proctoscopic examination was performed between 
10-12 am, using a $25 \mathrm{~cm}$ proctoscope, without prior administration of water enemas in any group. In each patient, three biopsy specimens were obtained from the lateral and posterior walls of the rectum at approximately $10 \mathrm{~cm}$ from the anal verge. One biopsy was immediately dipped in Bouin's fixative and processed for routine histological examination and pathological grading of colitis. Other biopsies were placed in Earle's basic salt solution supplemented with $10 \%$ calf serum (Institut Pasteur, Paris). Within five minutes after excision, they were cut in small strips of mucosa $-1 \mathrm{~mm} / 2 \mathrm{~mm}$ thick - which were transferred to $25 \mathrm{ml}$ flasks, and incubated in vitro for one hour in the same Earle's solution containing $10 \mu \mathrm{Ci} / \mathrm{ml}$ of methyl ${ }^{3} \mathrm{H}$ thymidine (Radiochemical Centre, Amersham; specific activity $5 \mathrm{Ci} / \mathrm{mmol}$ ). The flasks were gently agitated in a water bath at $37^{\circ} \mathrm{C}$. A mixture of $95 \%$ oxygen and $5 \%$ carbon dioxide was bubbled through the solution. The tissues were carefully washed with saline and incubated for an additional 20 minute period in medium without isotope to elute nonspecifically attached label. After rinsing small tissue strips were spread out and oriented on cardboard, fixed in Carnoy's fluid for 20 minutes, dehydrated, then embedded in paraplast. Tissue sections, $3 \mu \mathrm{m}$ thick, perpendicular to the surface of mucosa, were obtained, stained with the periodic acid-Schiff (PAS) sequence, coated with Ilford $\mathrm{K} 5$ emulsion and exposed for four weeks at $4^{\circ} \mathrm{C}$. The autoradiographs were developed in Kodak D19 and counterstained with haematoxylin. They were examined under oil immersion with 630 magnification. Only well oriented crypts longitudinally sectioned from base to surface and with a single layer of cells along the 'crypt column' (each side of the length of the crypt) were considered. The total number of cells and the number of the labelled cells per crypt column were scored. Position one was defined as the position occupied by the nucleus located at the centre of the gland base. Position of labelled cells was recorded from position 1 upwards to the surface. A cell was considered as labelled when six or more silver grains were visible overlying the nucleus (exceeding background at least four-fold). An average of 20 crypt columns yielding samples of 900-1500 crypt cell nuclei were analysed per subject, care was taken not to count the same crypt twice, even on tissue sections separated by more than 50 $\mu \mathrm{m}$. The labelling index or the percentage ratio of labelled nuclei to the total number of nuclei was calculated for each patient and for each group. To examine the spatial distribution of labelled cells, each crypt column was divided first successively in three equal parts (lower, middle, and upper third) then, for further precision, in five equal parts. ${ }^{17}$ The labelling index was also calculated for each of these parts. Statistical significance of differences between data obtained in the three groups resulted from variance analysis or non-parametric method (Wilcoxon's w test) whenever relevant. The level of statistical significance was set at $\mathrm{p}<0 \cdot 05$.

\section{Results}

I SIGMOIDOSCOPIC AND HISTOLOGICAL DATA AT THE TIME OF STUDY

All patients, except one ulcerative colitis, were in clinical remission.

\section{Proctoscopic appearance of rectal mucosa}

The appearance of rectal mucosa at the time of mucosal sampling was graded following Baron et al. ${ }^{18}$ The mucosal inflammation was found to be active only in one ulcerative colitis patient, moderately active in six ulcerative colitis and 12 ileorectal anastomosis-ulcerative colitis patients, inactive in two ulcerative colitis and seven ileorectal anastomosis-ulcerative colitis patients.

\section{Histopathological grading of rectal mucosa}

Only one ulcerative colitis patient had a major inflammation reaction with crypt abcesses and mild distortion of crypt architecture. Three ulcerative colitis and three ileorectal anastomosis-ulcerative colitis patients had lesions characterised by extensive infiltration of the mucosa with predominant mononuclear cells, and/or mild distortion of crypt architecture but without crypt abcess. The remaining patients had only mild inflammatory reaction with mononuclear cells and no appreciable architectural changes; among them seven patients showed a reduction in crypt number with oedema in the lamina propria. The epithelium always showed a well developed goblet cell population.

\section{MUCOSAL CELL PROLIFERATION DATA}

Generally tissue proved satisfactory for quantification except in one ileorectal anastomosis-ulcerative colitis and two ulcerative colitis in whom bad orientation of glands and/or fragment fragility did not allow examination of a sufficient number of glands, these patients were discarded. For the three groups of subjects, the length of crypt, expressed as the mean number of nuclei per crypt column, and the mean number of labelled cells per crypt were not different, with identicàl ranges (Table 1). Maximal intraindividual variation between two crypts within a single subject was, however, higher in ileorectal anastomosis-ulcerative colitis and ulcerative colitis groups than in controls, ranging from $25-80$ cells and 20-40 cells, respectively. 
Table 1 Parameters of cell proliferation in human rectal mucosa

\begin{tabular}{lll}
\hline & $\begin{array}{l}\text { Mean no cells* } \\
\text { per crypt column }\end{array}$ & $\begin{array}{l}\text { Mean no labelled cells* } \\
\text { per crypt column }\end{array}$ \\
\hline Ileorectal anastomosis-ulcerative colitis (18) & $69 \cdot 3 \pm 1 \cdot 5(58 \cdot 0-85 \cdot 6)$ & $6 \cdot 1 \pm 0 \cdot 3(3 \cdot 2-8 \cdot 4)$ \\
Ulcerative colitis (7) & $68 \cdot 4 \pm 3 \cdot 7(60 \cdot 5-85 \cdot 0)$ & $5 \cdot 7 \pm 0 \cdot 8(3 \cdot 0-8 \cdot 7)$ \\
Controls (10) & $71 \cdot 3 \pm 3 \cdot 1(61 \cdot 0-88 \cdot 7)$ & $5 \cdot 1 \pm 0 \cdot 5(3 \cdot 1-8 \cdot 1)$ \\
\hline
\end{tabular}

* mean value \pm 1 SEM and range between individuals.

$\dagger$ significantly different from controls, $p<0 \cdot 05$.

Number of patients in each group is indicated between parentheses.

Although the mean labelling index was significantly higher in ileorectal anastomosisulcerative colitis group than in controls $(p<0 \cdot 05$, Table 1), it remained low. The dispersion of individual labelling indices was similar in the three groups. When the labelling index was calculated in the different thirds of crypt column, a variance analysis revealed a significant difference between controls and ileorectal anastomosis-ulcerative colitis group in the upper third $(p<0 \cdot 05$, Table 2$)$. When the crypt column was divided in five parts the labelling index in the upper fifth was $1.6 \pm 0.4$, $1 \cdot 3 \pm 0 \cdot 6$, and $0 \cdot 5 \pm 0 \cdot 2$ in ileorectal anastomosisulcerative colitis, ulcerative colitis and control groups, respectively (NS). In the subjacent fifth the labelling index was respectively $5 \cdot 04 \pm 0 \cdot 8,6 \cdot 0 \pm 1 \cdot 3$, and $2.9 \pm 0.7(\mathrm{p}<0.05$ for ileorectal anastomosisulcerative colitis and ulcerative colitis groups compared with controls).

For the three groups no statistically significant correlation was found between labelling index and patient ages. For ulcerative colitis and ileorectal anastomosis-ulcerative colitis groups no correlation was found between labelling index and the total duration of the disease. Similarly, no correlation was observed between labelling index and the duration of the post-ileorectal anastomosis period. There was, however, a significant negative correlation between the pathological grading of colitis and the time elapsed after ileorectal anastomosis $(r=-0.52 ; p<0 \cdot 05)$. Rectal biopsies from female and male patients with ileorectal anastomosis disclosed comparable mean labelling index (respectively $8.7 \pm 0.9 \%$ and $8.9 \pm 0.7 \%$ ) as did rectal biopsies from ulcerative colitis patients (women, $8.9 \pm 1.2 \%$ and men $7 \cdot 1 \pm 1.9 \%$ ). No difference was found related to drug therapy.

In patients who were rebiopsied after an interval of several months or years, the labelling index in the two series of biopsies were of the same order (Table 3). Proctoscopic examination and pathological grading of colitis revealed improvement in patients nos 1 and 2, no change in mucosal inflammation in patient no 3 , and a slight worsening in patients nos 4 and 5.

Analysis of the labelling distribution throughout the length of crypt column showed that in the three groups the vast majority of labelled cells was located

Table 2 Statistical analyses of labelling results in ileorectal anastomosis-ulcerative colitis, ulcerative colitis and control groups (crypt area divided in three equal parts)

\begin{tabular}{|c|c|c|c|c|c|}
\hline & Crypt area & $\begin{array}{l}\text { Ileorectal } \\
\text { anastomosis- } \\
\text { ulcerative } \\
\text { colitis (18) }\end{array}$ & $\begin{array}{l}\text { Ulcerative } \\
\text { colitis (7) }\end{array}$ & Controls (10) & Statistics* \\
\hline $\begin{array}{l}\text { Labelling } \\
\text { distribution (\%) }\end{array}$ & $\begin{array}{l}\text { Lower } \\
\text { Middle } \\
\text { Upper }\end{array}$ & $\begin{array}{r}53 \cdot 2 \pm 3 \cdot 9 \\
37 \cdot 8 \pm 3 \cdot 3 \\
8 \cdot 9 \pm 1 \cdot 3\end{array}$ & $\begin{array}{l}48 \cdot 8 \pm 6 \cdot 7 \\
36 \cdot 2 \pm 3 \cdot 4 \\
15 \cdot 0 \pm 4 \cdot 8\end{array}$ & $\begin{array}{r}55 \cdot 2 \pm 4 \cdot 4 \\
40 \cdot 5 \pm 3 \cdot 9 \\
4 \cdot 4 \pm 1 \cdot 4\end{array}$ & $\begin{array}{l}\mathbf{N S}+ \\
\mathbf{N S}+ \\
\ddagger\end{array}$ \\
\hline $\begin{array}{l}\text { Labelling index }(\%) \\
\text { (mean value } \pm 1 \text { SEM) }\end{array}$ & $\begin{array}{l}\text { Lower } \\
\text { Middle } \\
\text { Upper }\end{array}$ & $\begin{array}{r}13 \cdot 6 \pm 0 \cdot 8 \\
10 \cdot 4 \pm 1.1 \\
2 \cdot 7 \pm 0 \cdot 5\end{array}$ & $\begin{array}{r}13 \cdot 0 \pm 2 \cdot 4 \\
9 \cdot 4 \pm 1 \cdot 3 \\
2 \cdot 8 \pm 1 \cdot 0\end{array}$ & $\begin{array}{r}11 \cdot 6 \pm 1 \cdot 3 \\
8 \cdot 8 \pm 1 \cdot 2 \\
1 \cdot 1 \pm 0 \cdot 4\end{array}$ & $\begin{array}{l}\mathbf{N S}+ \\
\mathbf{N S}+ \\
\S\end{array}$ \\
\hline
\end{tabular}

* Analysis of labelling distribution and of labelling index was performed using Student's $t$ test or Wilcoxon's test (W) when appropriate.

The number of subjects examined in each group is indicated between parentheses.

$\dagger$ No significant difference between the 3 groups.

$\ddagger p<0.05$ between IRA-UC and controls; $p<0.01$ between UC and controls (W).

$\S \mathrm{p}<0.05$ between IRA-UC and controls (W), NS between IRA-UC and UC and between UC and controls. 
Table 3 Successive studies of labelling index in rectal mucosa

\begin{tabular}{lcc}
\hline Patients & $\begin{array}{l}\text { Series Ilabelling } \\
\text { index }(\%)^{*}\end{array}$ & $\begin{array}{l}\text { Series II labelling } \\
\text { index }(\%)^{*}\end{array}$ \\
\hline N1 & $6 \cdot 1 \pm 2 \cdot()(8)$ & $8 \cdot 3 \pm 1 \cdot 5(22)$ \\
N2 & $13 \cdot 6 \pm 2 \cdot 5(12)$ & $12 \cdot 5 \pm 2 \cdot 4(22)$ \\
N3 & $12 \cdot 8 \pm 4 \cdot 1(10)$ & $7 \cdot 8 \pm 1 \cdot 3(20)$ \\
N4 & $8 \cdot 9 \pm 1 \cdot 5(16)$ & $9 \cdot 5 \pm 1 \cdot 6(22)$ \\
N5t & $12 \cdot 9 \pm 2 \cdot 5(14)$ & $11 \cdot 5 \pm 2 \cdot 0(20)$ \\
Mean & $10 \cdot 9 \pm 1 \cdot 6$ & $9 \cdot 9 \pm 1 \cdot 0$ \\
\hline
\end{tabular}

Number of crypt columns examined in each patient rectal mucosa was indicated between parentheses.

* mean value $\pm 1 \mathrm{SEM}$.

+ UC patients; the others are IRA-UC patients. in the lower and middle thirds of glands (Fig. 3, Table 2). An average of 9,15 , and $4.4 \%$ of them were, however, encountered in the upper third in ileorectal anastomosis-ulcerative colitis, ulcerative colitis and control groups, respectively; both ileorectal anastomosis-ulcerative colitis and ulcerative colitis groups differed significantly from controls. When the crypt was divided in five parts, significant differences were found in the upper two-fifths between the three groups. In the upper fifth the percentage of labelled cells was $3 \cdot 1 \pm 0 \cdot 6$, $4 \cdot 0 \pm 2 \cdot 1,1 \cdot 1 \pm 0.5$ for ileorectal anastomosisulcerative colitis, ulcerative colitis and control groups, respectively $(\mathrm{p}<0.05$ between ileorectal

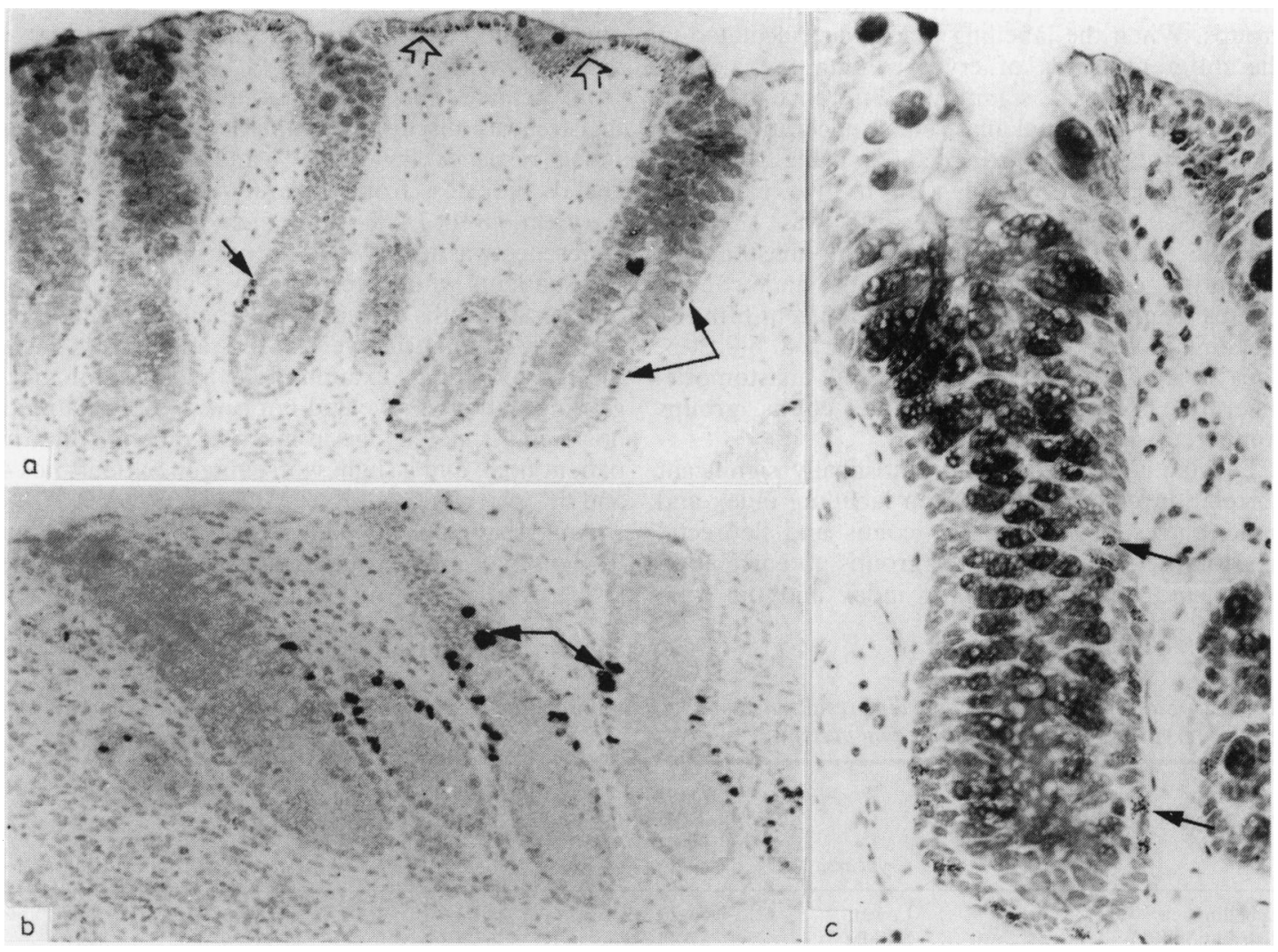

Fig. 3 Autoradiographs of rectal biopsies after in vitro methyl- ${ }^{3} \mathrm{H}$-thymidine labelling. Mucous substances are stained by the PAS sequence.

(a) IRA-UC patient showing regression of inflammatory process with oedema and PAS positive mucous granules in superficial epithlium (empty arrows). LI=8.7\%. Labelled cells were confined in lower one-third of crypts (black arrows) (original magnification $\times 170$ ).

(b) UC patient showing mild inflammatory lesions. In this picture labelled cells (arrows) are located in middle third of crypts; $L I=10 \%$. Stage ' $B$ ' abnormality. Surface epithelium was disrupted (original magnification $\times 170$ ).

(c) Detail of crypt in another IRA-UC patient showing labelled cells (arrows) in the lower two-thirds of crypt. LI=7.8\%. Note the well-developed goblet cells (original magnification $\times 340$ ). 
anastomosis-ulcerative colitis and controls). In the subjacent fifth the percentage of labelled cells was respectively $10 \cdot 8 \pm 1 \cdot 3,16 \cdot 8 \pm 3 \cdot 0$, and $7 \cdot 5 \pm 1 \cdot 9$ (NS between ileorectal anastomosis-ulcerative colitis and control groups and $p<0.05$ between ulcerative colitis and the other two groups; data not shown). As a range of $0-5 \%$ of labelled cells in the upper third of the crypt has already been reported in normal mucosa, ${ }^{17}$ in each individual, proliferative pattern abnormalities were defined as follows: stage ' $A$ ' abnormality when $6 \%$ or more labelled cells were found in the upper third, and stage ' $B$ ' abnormality when in addition, $50 \%$ or more labelled cells were located in the upper two thirds of the crypt. For each subject both labelling index and proliferative pattern of labelled cells are shown in Figure 4. Only four patients showed a shift of the major zone of proliferation: from the lower to the middle third of the crypt (three ileorectal anastomosis-ulcerative colitis patients) and from the lower to the upper third of the crypt (one ulcerative colitis patient). Seven of 18 ileorectal anastomosisulcerative colitis patients had a quite normal

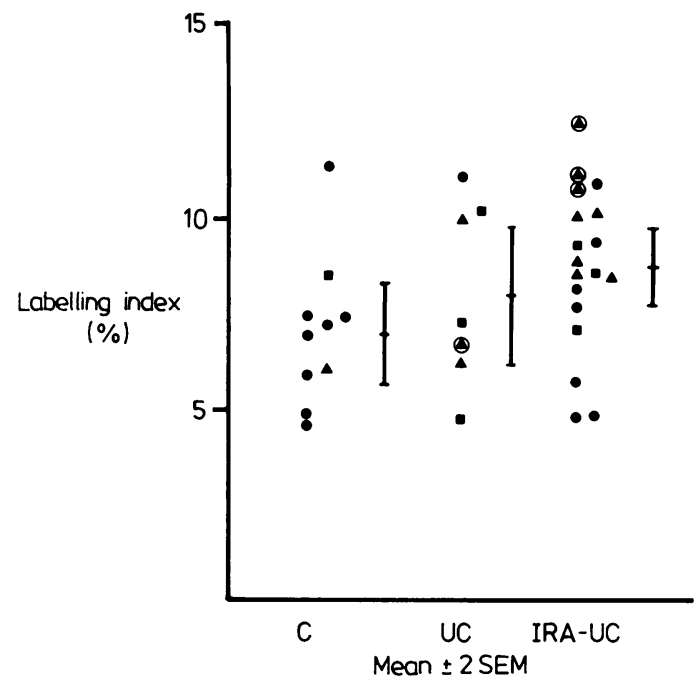

Fig. 4 Individual and mean ( $\pm 2 S E M$ ) labelling indices in three groups of subjects. $C=$ controls, $U C=$ ulcerative colitis, IRA-UC = ulcerative colitis with ileorectal anastomosis. Mean labelling index in IRA-UC is significantly different from that noted in controls, $p<0.05$. (O) Normal proliferative pattern in crypt, ( $\square$ ) stage ' $A$ ' abnormality: extension of labelled cells in the upper third, (A) stage ' $B$ ' abnormality: more than $50 \%$ of labelled cells in middle and upper thirds of crypt, (Q) shift of major zone of proliferation from lower to middle (IRA-UC) or to upper third (UC) of crypt. proliferative pattern - that is, normal labelling index, normal labelled cell distribution - among them, five had a longstanding colitis (over 10 years) and have undergone ileorectal anastomosis for a relatively long period (mean 7.5 years).

\section{Discussion}

Based on the present results the following points will be discussed (a) the validity of technical procedure, (b) the comparison of our findings in ulcerative colitis patients with the literature and (c) the possible clinical implication of those noted in ileorectal anastomosis-ulcerative colitis patients.

It seems that when using the in vitro labelling technique, radioactive precursors diffuse slowly into specimens. ${ }^{19}$ Several factors interplay to ensure a correct uptake: the duration of incubation, the size of tissue samples, the concentration of precursor in medium. In previous studies the time of incubation with isotope varies from $15-30$ minutes $^{11}{ }^{19-20}$ to several hours. ${ }^{12} 14-1521$ After preliminary trials using 15 minute incubation we chose a 1 hour period which was reported to give satisfactory results. ${ }^{17}$ The dose of radioactive precursor added to the medium was similar to that previously used by others. ${ }^{11} 1221$ In one control subject half of the biopsies were incubated with $10 \mu \mathrm{Ci} / \mathrm{ml}$ of ${ }^{3} \mathrm{H}$ thymidine and the other half with $1 \mu \mathrm{Ci} / \mathrm{ml}$ of the same precursor; the labelling index obtained for one hour incubation were of the same order $(7 \cdot 14 \pm 0.94 \%$ and $6 \cdot 65 \pm 0.91 \%$, respectively). Biopsies from the three groups were always processed in the same technical conditions. Any possibility of circadian rhythm influence was eliminated as all biopsies were excised during the same short morning period. Care was taken to restrict counts to crypts located in selected areas where labelling was uniform and reproducible. Using this methodology, labelling index values noted in our controls were in accordance with previous data observed after a short period of in vitro labelling in normal human rectal mucosa: a range for labelling index from $5 \cdot 7$ to $15 \%^{11}$ and from 3.4 to $15.4 \%{ }^{17}$ were noted, close to that found in our series (from 4.7 to $11.4 \%$ ). Previous studies have shown that in the colon, the epithelial proliferative zone is normally confined to the lower and middle thirds of the gland. ${ }^{11-12} 1722$ As already reported in normal human mucosa, ${ }^{17}$ a mean of $4.4 \%$ labelled cells was noted in the upper third of the crypt in our controls. In two of them, an upward extension of the proliferative compartment was observed (Fig. 4). No known personal of familial clinical history suggested that they belong to a group at high risk for colonic neoplasia. Such abnormal ${ }^{3} \mathrm{H}$-thymidine 
incorporation pattern has also been occasionally noted in colonic mucosa of control subjects with no gastrointestinal disease. ${ }^{23}$

Two main factors seem involved in the alteration of the epithelial cell proliferation kinetics in ulcerative colitis: (a) the degree of mucosal inflammation, (b) the duration of the disease. In active ulcerative colitis an increase in epithelial cell proliferation as well as an extension of the proliferative zone towards the upper part of the crypt have been reported. ${ }^{11}$ In ulcerative colitis in remission similar patterns to those seen in active ulcerative colitis were found ${ }^{14}$ which were not totally confirmed by others. ${ }^{15}$ In the later work there was no significant enhancement of the labelling index but there were abnormalities in the distribution of labelled cells in crypts, which appeared more evident when the disease duration exceeded 10 years. A loss of control of thymidine incorporation has been shown in longstanding ulcerative colitis in remission. ${ }^{16}$ The authors pointed out that duration of inflammation changes, rather than the extent of the disease within the colon, may be the most important factor leading to the alteration in control of DNA synthesis.

Although we investigated a small group of unoperated patients, their mean labelling index was not significantly different from that of controls. These patients (except one), however, showed some degree of abnormality in the distribution of labelled cells. One had a low labelling index, $6.9 \%$, but showed $43 \%$ of the labelled cells in the upper third of the crypt (major zone of proliferation) (Fig. 4). These findings are in full accordance with recent Italian reports. ${ }^{15}$ In none of our ulcerative colitis patients did histopathological analysis of material obtained from biopsies taken during colonoscopic examination, show any sign of severe colonic dysplasia.

This study provides for the first time data on mucosal cell kinetics in the rectal stump of ulcerative colitis patients in whom intestinal continuity had been restored after total colectomy. The following observations were made: (a) there was a significant increase of the mean labelling index compared with controls. Nevertheless individual labelling indices were within the normal range in reference to our own controls as well as to other controls similarly studies. ${ }^{11} 17$ In any case labelling index remained low and very different from those noted in active ulcerative colitis (up to $26 \%$ ) ${ }^{11}$ (b) there was no difference for the mean crypt length and the mean number of labelled cells per crypt between the ileorectal anastomosis-ulcerative colitis and control groups (Table 1); (c) 11 of 18 ileorectal anastomosisulcerative colitis patients exhibited a noticeable percentage of labelled cells in the upper third (up to
$20 \%$, mean $8.9 \%$ ), three of them has a shift of the major proliferative zone from the lower to the middle third of the crypt. These observations must be discussed in further details because of their possible clinical relevance if mucosal cell proliferation abnormalities are related to cancer risk. ${ }^{13} 24$ The ileorectal anastomosis-ulcerative colitis patients studied here are fully representative of the whole group of 52 ileorectal anastomosisulcerative colitis patients regularly followed in our institution. They were strictly selected: indeed, ileorectal anastomosis was not performed when cancer or precancerous lesions were present either on the rectum or on the remainder of the colon. ${ }^{25}$ Although most of ileorectal anastomosis-ulcerative colitis patients presently investigated had universal colitis at the time of surgery, a low degree of mucosal inflammation was noted in the vast majority of the subjects at the time of the study. Our results seem consistent with (a) the noteworthy lower incidence of carcinoma in the rectal stump than in unoperated patients with chronic ulcerative colitis, given the same duration of the disease, $;^{2426}$ (b) the usual regression of the inflammatory process after ileorectal anastomosis ${ }^{127-28}$ whether or not it is related to restoration of a normal contact with the ileofaecal stream. ${ }^{29}$ By comparison with ulcerative colitis patients, ileorectal anastomosis-ulcerative colitis seemed to exhibit a lesser degree of anomalies in proliferative parameters within the rectal mucosa. Accordingly, in the whole, less labelled cells were observed in the upper third of the crypt in ileorectal anastomosis-ulcerative colitis than in ulcerative colitis groups (Table 2). Among the ileorectal anastomosis-ulcerative colitis patients with a disease duration exceeding 10 years, $42 \%$ had a labelling index ranging from 4.9 to 11.6 (normal values) with a quite normal pattern of proliferation (no extension in the upper third, major zone of proliferation in the lower third of the crypt) (Fig. 4). The latter individuals, but one, have the longest post-ileorectal anastomosis periods. For example the patient with a 42.7-year disease duration and a 8.3-year postileorectal anastomosis period showed the lowest labelling index. These facts are at variance with those found in our own series of longstanding ulcerative colitis as well as with those reported in recent studies in ulcerative colitis in remission. ${ }^{14-15}$ Indeed in these three sets of studies, all patients with ulcerative colitis lasting for over 10 years exhibited abnormal labelled cell distribution. Thus, in ileorectal anastomosis-ulcerative colitis patients two opposite elements might conflict at the mucosal level: on the one hand the disease duration which would lead to abnormalities in mucosal cell proliferation, ${ }^{16}$ perhaps to severe dysplasia and 
cancer ${ }^{24-7}$ and, on the other hand, the return towards a near normal aspect of the rectal mucosa which would reduce the risk of premalignant change. ${ }^{30}$ Nevertheless the demonstration of an extension of the proliferative compartment in $60 \%$ and of a shift of the major proliferative zone in $17 \%$ of ileorectal anastomosis-ulcerative colitis patients obviously indicate that these patients belong to a group at risk for rectal neoplasia and commands regular proctoscopic and histological follow-up. The case of Dukes A rectal carcinoma that was recently diagnosed (non-included in this study) is fully confirmative.

Further studies conducted on a larger group of ileorectal anastomosis-ulcerative colitis patients are needed to check our observations. Although some patients offered no difference in labelling index estimated at 10-30 month intervals, we need also to ascertain that, in the same series of ileorectal anastomosis-ulcerative colitis patients, no alteration in the rectal epithelial cell kinetics develops as the duration of follow-up increases.

The authors wish to acknowledge Dr C Vissuzaine for histopathological examination, Drs J Vilotte, and $\mathrm{J} F$ Guillard for their clinical assistance, Mrs L Grès for skillful technical assistance, Mrs F Pamart and M Sauvadet for their help in preparing the manuscript. This work was supported by INSERM (grant ATP no 8279114 38).

\section{References}

1 Aylett SO. Diffuse ulcerative colitis and its treatment by total cole tomy and ileo-rectal anastomosis. Ann $R$ Coll Surg Engl 1960; 27: 260-84.

2 Grundfest SF, Fazio V, Weiss RA, et al. The risk of cancer following colectomy and ileorectal anastomosis for extensive mucosal ulcerative colitis. Ann Surg 1981; 193: 9-14.

3 Loygue J, Levy E, Michel F, Parc R, Huguet C, Malafosse M. Faut-il conserver le rectum lors du traitement chirurgical de la rectocolite hémorragique? Étude de 198 tentatives de conservation rectale. Gastroenterol Clin Biol 1981; 5: 1146-54.

4 Baker WNW, Glass RE, Ritchie JK, Aylett SO. Cancer of the rectum following colectomy and ileorectal anastomosis for ulcerative colitis. Br J Surg 1978; 65: 862-8.

5 De Dombal FT, Watts J, Watkinson G, et al. Local complications of ulcerative colitis; structure, pseudopolyposis and carcinoma of colon and rectum. Br Med J 1966; 1: 1442-7.
6 Lennard-Jones JE, Morson BC, Ritchie JK, Shove DC, Williams CB. Cancer in colitis: assessment of the individual risk by clinical and histological criteria. Gastroenterology 1977; 73: 1280-9.

7 Greenstein AJ, Sachar DB, Smith H, et al. Cancer in universal and left-sided ulcerative colitis: factors determining risk. Gastroenterology 1979; 77: 290-4.

8 Morson BC, Pang LSC. Rectal biopsy as an aid to cancer control in ulcerative colitis. Gut 1967; 8: 423-34.

9 Shorter RG, Spencer RJ, Hallenbeck GA. Kinetic studies of the epithelial cells of the rectal mucosa in normal subjects and patients with ulcerative colitis. Gut 1966; 7: 593-6.

10 Spencer RJ, Huizenga KA, Hammer CS, Shorter RG. Further studies of the kinetics of rectal epithelium in normal subjects and patients with ulcerative or granulomatous colitis. Dis Colon Rectum 1969; 12: 406-8.

11 Bleiberg $\mathrm{H}$, Mainguet $\mathrm{P}$, Galand $\mathrm{P}$, Chrétien J, Dupont-Mairesse $\mathbf{N}$. Cell renewal in the human rectum. In vitro autoradiographic study on active ulcerative colitis. Gastroenterology 1970; 58: 851-5.

12 Eastwood GL, Trier JS. Epithelial cell renewal in cultured rectal biopsies in ulcerative colitis. Gastroenterology 1973; 64: 383-90.

13 Deschner EE, Katz S, Katzka I, Kahn E. Proliferative defects in ulcerative colitis patients. (Abstract) Gastroenterology 1980; 78: 1155 .

14 Serafini EP, Kirk AP, Chambers TJ. Rate and pattern of epithelial cell proliferation in ulcerative colitis. Gut 1981; 22: 648-52.

15 Biasco G, Miglioli M, Minarini V, et al. Rectal cell proliferation and cancer risk in ulcerative colitis: a preliminary report. Ital J Gastroenterol 1982; 14: 76-9.

16 Alpers DH, Philpott G, Grimme NL, Margolis DM. Control of thymidine incorporation in mucosal explants from patients with chronic ulcerative colitis. Gastroenterology 1980; 78: 470-8.

17 Maskens AP, Deschner EE. Tritiated thymidine incorporation into epithelial cells of normal-appearing colorectal mucosa of cancer patients. J Natl Cancer Inst 1977; 58: 1221-4.

18 Baron JH, Connel AM, Lennard-Jones JE. Variation between observers in describing mucosal appearances in proctocolitis. $\mathrm{Br}$ Med J 1964; 1: 89-92.

19 Galand P, Mainguet P, Arguello M, Chrétien J, Douxfils N. In vitro autoradiographic studies on cell proliferation in the gastrointestinal tract of man. $\mathrm{J} \mathrm{NuCl}$ Med 1968; 9: 37-9.

20 Bransom CJ, Boxer ER, Palmer KR, Clark JC, Underwood JCE, Duthie HL. Mucosal cell proliferation in duodenal ulcer and duodenitis. Gut 1981; 22: 277-82.

21 Eastwood GL, Trier JS. Organ culture of human rectal mucosa. Gastroenterology 1973; 64: 375-82.

22 Lipkin M, Bell B, Sherlock P. Cell proliferation kinetics in the gastrointestinal tract of man. I. Cell renewal in colon and rectum. J Clin Invest 1963; 42: 767-76.

23 Deschner EE, Lipkin M. Proliferative patterns in colonic mucosa in familial polyposis. Cancer 1975; 35: 413-8. 
24 Lipkin M. Phase 1 and phase 2 proliferative lesions of colonic epithelial cells in diseases leading to colonic cancer. Cancer 1974; 34: 878-88.

25 Mignon $\mathrm{M}$, Bonnefond $\mathrm{A}$, Vilotte $\mathrm{J}$, et al. Les indications de la conservation du rectum dans les colectomies pour rectocolite hémorragique. Arch Fr Mal App Dig 1974; 63: 541-53.

26 Hugues ESR, McDermott FT, Masterton JP. Ileorectal anastomosis for inflammatory bowel disease: 15 -year follow-up. Dis Colon Rect 1979; 22: 399-400.

27 Vissuzaine C, Danne O, Jouglen J, Soullard J, Mignon M. Les lésions histologiques du rectum restant après anastomose iléorectale pour rectocolite hémorragique.
Méthodes d'analyses et interprétation des résultats dans la surveillance à long terme. Gastroenterol Clin Biol 1979; 3: 631-6.

28 Ribet M, Wurtz A, Paris JC et al. La conservation du rectum dans la chirurgie de la rectocolite hémorragique (étude à long terme de 73 opérés). Gastroenterol Clin Biol 1981; 5: 1140-5.

29 Glotzer DJ, Glick ME, Goldman H. Proctitis and colitis following diversion of the fecal stream. Gastroenterology 1981; 80: 438-41.

30 Nugent FW, Haggit RC, Colcher H, Kutteruf GC. Malignant potential of chronic ulcerative colitis. Preliminary report. Gastroenterology 1979; 76: 1-5. 